\title{
Salmon lice infection on wild salmonids in marine protected areas: an evaluation of the Norwegian 'National Salmon Fjords'
}

\author{
R. M. Serra-Llinares ${ }^{1, *}$, P. A. Bjørn ${ }^{1}$, B. Finstad ${ }^{2}$, R. Nilsen $^{1}$, A. Harbitz ${ }^{1}$, M. Berg ${ }^{2}$, \\ L. Asplin ${ }^{1}$
}

${ }^{1}$ Institute of Marine Research, PO Box 6404, 9294 Tromsø, Norway

${ }^{2}$ Norwegian Institute for Nature Research, PO Box 5685, 7485 Trondheim, Norway

\begin{abstract}
In Norway, 29 fjords and 52 rivers have been designated for protection in order to prevent the infection of important populations of wild salmonids with salmon lice of farm origin. We evaluated the effect of this protection on the lice infection pressure for wild salmonids based on lice counts performed on wild-caught sea trout and Arctic charr inside onethird of these protected fjords (known as 'National Salmon Fjords'). Results indicate that these areas may provide a certain extent of protection against lice of farm origin, but their configuration will play a key role in their success. When the size and shape of a protected area are such that fish farms are kept at a minimum distance (calculated here as at least $30 \mathrm{~km}$, but this distance is likely site-dependent), wild fish seem unaffected by the direct lice infection pressure imposed by fish farms. In contrast, the effects of small protected fjords were strongly dependent on the production pattern of the aquaculture industry in the surrounding area, and we found a clear correlation between lice levels on wild salmonids and lice production in nearby salmon farms. To establish more precise management practices, both in National Salmon Fjords and other fjord systems along the Norwegian coast, the development and validation of accurate distribution and abundance models for the dispersion of planktonic lice larvae is needed; this could also be the basis for an area management system based on 'maximum sustainable lice loads' or 'lice quotas.'
\end{abstract}

KEY WORDS: Sea trout $\cdot$ Salmo trutta $\cdot$ Arctic charr · Salvelinus alpinus $\cdot$ Lepeophtheirus salmonis $\cdot$ Area protection

\footnotetext{
${ }^{*}$ Corresponding author: rosa.maria.serra.llinares@imr.no
}

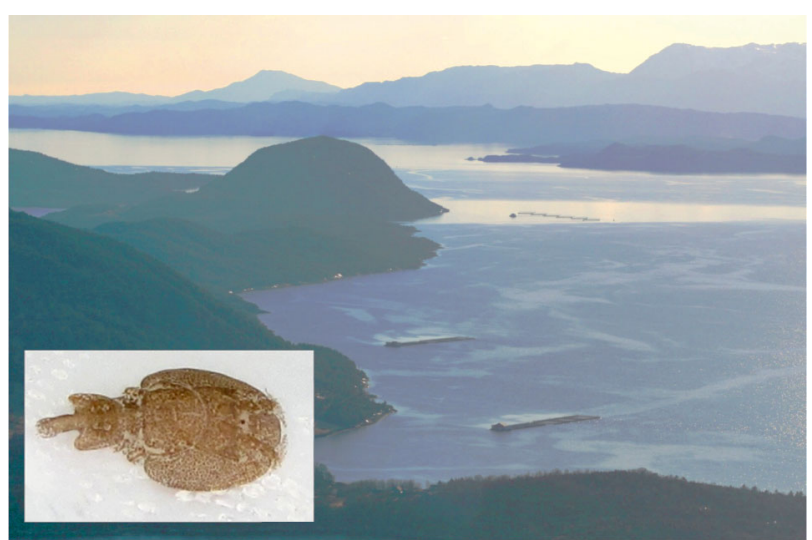

Salmon farms outside the National Salmon Fjord in Hardanger, Norway. Inset: adult female salmon lice Lepeophtheirus salmonis

Photo: Rune Nilsen

\section{INTRODUCTION}

The salmon louse Lepeophtheirus salmonis Kröyer is a specialist ectoparasite commonly found on wild and farmed salmonids in the marine environment (see Finstad et al. 2011, Finstad \& Bjørn 2011, and references therein). The spread of salmon lice from fish farms to wild fish has been a major issue in the last decade for the management of sustainable aquaculture (see reviews by Costello 2006, 2009 and references therein). Because of the high numbers of hosts held in sea cages, the density of planktonic salmon louse larvae in areas of intensive farming can reach several orders of magnitude higher than in

(C) The Authors 2014. Open Access under Creative Commons by Attribution Licence. Use, distribution and reproduction are unrestricted. Authors and original publication must be credited. 
farm-free areas (Butler 2002, Krkošek et al. 2005, Jansen et al. 2012), resulting in an increased lice infection risk for local populations of wild salmonids (Bjørn et al. 2001, 2011, Gargan et al. 2003, Morton et al. 2004, 2008, Middlemas et al. 2010, 2013). Annual salmon louse epidemics on wild sea trout Salmo trutta L. and Arctic charr Salvelinus alpinus L. have been reported in the last 20 yr from Norway (see Finstad \& Bjørn 2011 and references therein), Ireland, and Scotland (see Finstad et al. 2011 and references therein). Further, recent studies have shown that salmon louse epidemics may have an important role in the decline of some stocks of wild Atlantic salmon Salmo salar L. in Norway (Barlaup 2013, Krkošek et al. 2013, Skilbrei et al. 2013) and Ireland (Gargan et al. 2012, Jackson et al. 2013, Krkošek et al. 2013, Torrissen et al. 2013) and of pink salmon Oncorhynchus gorbuscha in British Columbia, Canada (Krkošek et al. 2007, Krkošek \& Hilborn 2011).

The spread of the lice occurs during the free-living naupli and copepodid stages, as they are free drifting with the water currents. The amount of infective larvae produced in an area will depend on the number of hosts (wild and/or farmed) and the number of mature female lice per host, and the production is known to be modulated by water temperature (Boxaspen \& Næss 2000, Heuch et al. 2000, Stien et al. 2005). Once released in the water, the larvae must find a host in the course of approximately 150 degree-days (i.e. $15 \mathrm{~d}$ at $10^{\circ} \mathrm{C}$; Asplin et al. 2011). Within this time, the lice will be transported by the water currents, with the scope of the dispersion varying largely from site to site. Several coupled hydrodynamic-biological models have been developed in recent years attempting to predict the spread of lice from fish farms under varying environmental scenarios (see Costello 2009 and references therein, Asplin et al. 2011, Stucchi et al. 2011, Salama et al. 2013). These models agree in predicting a high heterogeneity in the dispersion of lice, but also suggest that most particles tend to concentrate within $30 \mathrm{~km}$ from the source (Gargan et al. 2003, Krkošek et al. 2005, Asplin et al. 2011, Middlemas et al. 2013, Salama et al. 2013) even though a small number of particles could be transported much longer distances (>200 km) in large fjord systems and along the coast (Asplin et al. 2011).

Norway is the world's largest producer of salmonid fish, with around 1.2 billion $t$ of Atlantic salmon and rainbow trout Oncorhynchus mykiss produced in 2012 (the Norwegian Directorate of Fisheries, www. fiskeridir.no). Fish farms are distributed along the entire coast, and the number of farmed fish varies throughout the year depending on releases of smolts and harvest levels, with the highest biomass normally reported in the period October to December. In addition, Norway holds most of the remaining Atlantic salmon populations in the Northern Atlantic and has international responsibility in the conservation of wild salmon stocks through the Convention for the Conservation of Salmon in the North Atlantic Ocean (TIAS 10789), 1982 (www.nasco.int/convention. html). In order to protect important stocks of wild salmonids from potential negative effects associated with salmon farming, particularly from the infection with salmon lice, the Norwegian government has implemented a range of management strategies. These include mandatory reporting of lice, legal limits on salmon louse abundance on farmed fish, synchronized delousing and fallowing of farms within management areas, and protection of important salmon rivers and coastal areas, where strict restrictions on salmon aquaculture should apply (Norwegian Food Safety Authorities, www.mattilsynet.no).

Protection of important Norwegian salmon fjords (see Aasetre \& Vik 2013 and references therein) began with the establishment of temporary safety zones in 1989 (NOU 1990) and later developed into an integrated coastal zone management process (Sønvisen 2003). After these zones were evaluated and the establishment of protected salmon fjords and rivers was suggested in a White Paper (NOU 1999), 29 protected salmon fjords and 52 protected rivers were established (Aasetre \& Vik 2013). Inside the protected salmon fjords (termed 'National Salmon Fjords'), restrictions to aquaculture practices (see Bjørn et al. 2011) are presumed to establish a spatial separation between salmon lice of farm origin and local populations of wild salmonids. It has been suggested that area protection might benefit local populations of wild salmonids to some extent, but the achieved protection against salmon lice might be dependent on the size and conformation of the protected area, with small areas showing limited protection compared to completely farm-free fjords (Bjørn et al. 2011). This can be explained by the horizontal dispersion of lice infective stages from surrounding areas, or by the fish visiting other parts of the fjord where the infection risk imposed by fish farms might be high.

The aim of the present paper was to perform a midterm evaluation of the National Salmon Fjords in terms of their efficacy in protecting wild salmonids from an increased salmon lice infection risk derived from fish farming activities. For this purpose, salmon lice counts performed on wild sea trout and Arctic charr caught between 2008 and 2012 as a part of the Norwegian national sea lice monitoring program 
were examined. Further, available farm data mandatorily reported between 2010 and 2012 by the industry to the Norwegian authorities were analyzed to assess the possible influence of lice of farm origin on the lice abundance registered on wild salmonids.

\section{MATERIALS AND METHODS}

\section{Study area}

Sea lice infection levels on wild salmonids have been systematically monitored and reported to the Norwegian management authorities for the last $15 \mathrm{yr}$ all along the Norwegian coast as part of the national strategy to protect important stocks of wild salmonids (Bjørn et al. 2012). The national sea lice monitoring program has varied in intensity throughout the years, but it is currently fairly extensive and includes sampling locations distributed in 15 different fjord systems covering the whole length of the Norwegian coast (Fig. 1).

There are currently 29 National Salmon Fjords in Norway (Aasetre \& Vik 2013; Table 1). Some of them cover fairly large areas, such as the Trondheimsfjord and the Tanafjord (1526 and $809 \mathrm{~km}^{2}$, respectively), while others occupy much smaller areas situated in regions of intensive farming, such as Ørstafjord and Nordfjord (16 and $23 \mathrm{~km}^{2}$, respectively) among others. Even though the Norwegian national sea lice monitoring program was not initially designed for evaluating the effect of area protection, it now includes a total of 9 sampling locations situated inside National Salmon Fjords (Fig. 1, Table 1). These locations cover the length of the Norwegian coast, from Porsangerfjord in the north to Hardangerfjord in the southwest, and include both large and small protected areas, open coastal areas and inner fjords, and areas with none to very intensive salmon farming activity (Fig. 1). Based on the available knowledge about the potential spread of lice from their point of origin, the 9 National Salmon Fjords investigated in this study were classified as 'large' or 'small' protected areas. A protected area was defined as 'large' when the closest active fish farm was situated more than $30 \mathrm{~km}$ (sea-way distance) from the corresponding sea trout sampling location during the $5 \mathrm{yr}$ investigation, and as 'small' when at least 1 active fish farm was present within $30 \mathrm{~km}$ of the corresponding sea trout location in at least 1 of the years investigated. This classification is thus not entirely dependent on the size of the protected area but also depends on its shape, on the situation of the sea trout sampling location, and on the distribution of salmon farms outside the limits of the protection.

\section{Salmon lice infection on wild salmonids}

Salmon lice counts on wild sea trout and Arctic charr (henceforth referred to as sea trout for simplification) reported between 2008 and 2012 as a part of the Norwegian national sea lice monitoring program were used in the present study. These species are good indicators of the local sea lice infection pressure because, as opposed to Atlantic salmon smolts, which ultimately leave the fjord environment in their migration out to sea, they spend most of their seawater phase inside the fjords, within close range of their native rivers (Lyse et al. 1998, Rikardsen et al. 2000, Sivertsgård et al. 2007). No differences in lice intensity are expected between these 2 species (Bjørn \& Finstad 2002). Sampling was performed in fixed locations distributed all along the Norwegian coast at most sites twice per year: May to June (during the salmon smolt run) and June to August (during the sea-phase of sea trout and Arctic charr). Sampling at sea was performed with floating gill nets $(3 \mathrm{~m}$ long $\times$ $1.5 \mathrm{~m}$ deep, mesh sizes $21 / 26 \mathrm{~mm}$ ); the nets were anchored above high tide level with an angle of approximately $90^{\circ}$ to the shore, and across the littoral zone in which most of the sea trout and Arctic charr forage. The nets were continuously observed and cleaned, moved or reset whenever necessary; caught fish were removed without delay to prevent losses of lice. Sampled fish were gently cut out of the nets, placed in individual plastic bags and brought to the laboratory for later examination. In the laboratory, captured fish were measured to the nearest millimeter, weighed to the nearest $0.1 \mathrm{~g}$, and examined under an illuminated magnifying glass $(10 \times)$. Sea lice stages (chalimus, pre-adult, and adult) were identified on a morphological basis according to Johnson \& Albright (1991) and Schram (1993).

The infection terms used in present study (prevalence, mean abundance, and mean intensity) are those recommended by Bush et al. (1997) and refer to total numbers of lice. Lice loads registered on wild sea trout caught inside National Salmon Fjords were examined in order to detect possible peaks of infections, i.e. high prevalence together with high mean intensity compared to a natural infection (characterized by occasional high prevalence but low intensity, typically under 10 lice fish $^{-1}$ at its highest in autumn; Tingley et al. 1997, Schram et al. 1998, Bjørn \& Finstad 2002, Rikardsen 2004). 


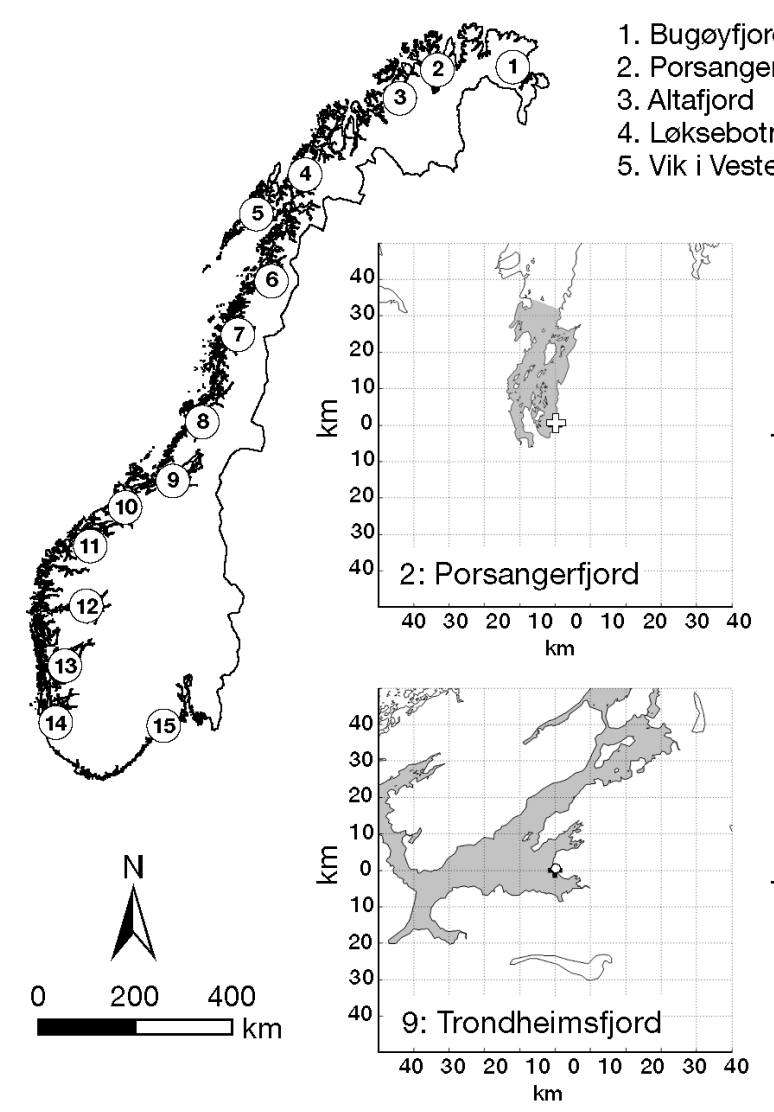
1. Bugøyfjord
6. Folda
7. Vefsnfjord
8. Namsfjord
9. Trondheimsfjord
10. Romsdalsfjord
4. Løksebotn

11. Storfjord

12. Sognefjord

13. Hardangerfjord

14. Jæren-Dalane (Rogaland)

10. Romsdalsfjord

15. Sandnesfjord
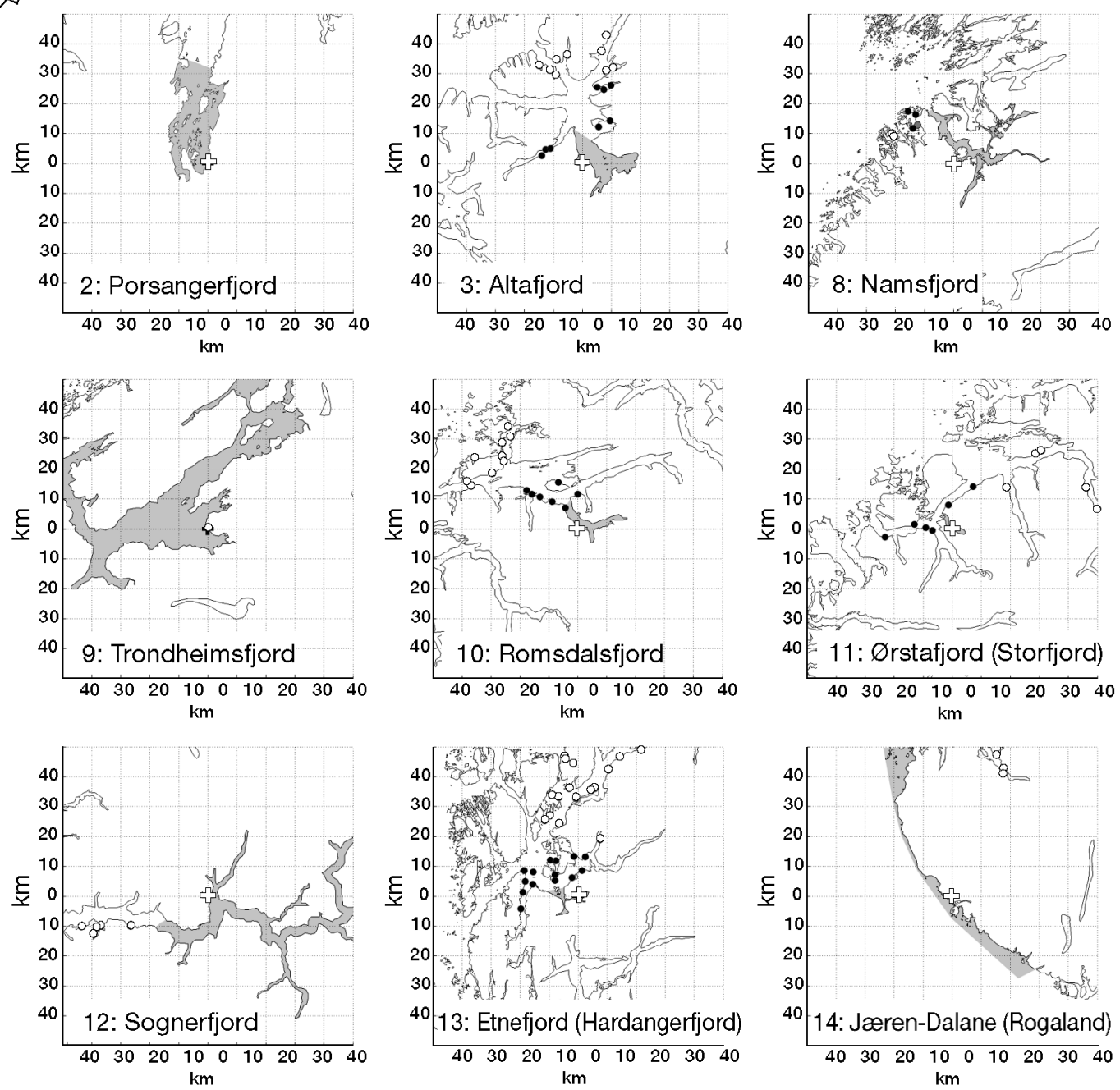

Fig. 1. Locations of all fjords included in the Norwegian national sea lice monitoring program in the period 2008 to 2012 . The 9 National Salmon Fjords included in the monitoring program and evaluated in this study are shown in more detail from north to south: shaded areas indicate the extent of the protected areas; white crosses (§) indicate the approximate sea trout sampling locations; black dots indicate salmon farms situated $<30 \mathrm{~km}$ sea-way distance from the sea trout sampling location; white dots indicate other salmon farms ( $>30 \mathrm{~km}$ sea-way distance from the sea trout sampling location). Not all farms indicated in the maps were active during the whole study period

To assess the impact of a given sea lice infection level in terms of population regulating effects, we used the risk index proposed by a group of Norwegian experts for out-migrating salmon smolts and first-time out-migrating sea trout and Arctic charr (Taranger et al. 2012). This index is based on best available knowledge and estimates the expected increase in mortality risk due to sea lice in a given population of wild salmonids based on the proportion of fish having different lice infection levels, meas- ured as the number of lice per gram of fish weight. Based on a number of studies undertaken both in Norway (Grimnes \& Jakobsen 1996, Bjørn \& Finstad 1997, Finstad et al. 2000, 2011, Bjørn et al. 2001, Holst et al. 2003, Wagner et al. 2003, 2008, Tveiten et al. 2010, Finstad \& Bjørn 2011) and in other countries (Nolan et al. 1999, Johnson \& Fast 2004, Fast et al. 2006), an infection level of 0.10 lice per gram of fish weight (i.e. 10 lice on a $100 \mathrm{~g}$ fish) was set as a conservative limit for the onset of physiological effects of 
Table 1. National Salmon Fjords $(n=29)$ currently found in Norway organized by size $\left(\mathrm{km}^{2}\right)$. Fjords where wild sea trout were sampled at least once as a part of the national sea lice monitoring program are highlighted in bold, and the distance between the sampling location and the closest fish

farm (sea-way distance) is specified; no data (nd) is indicated otherwise

\begin{tabular}{|llcc|}
\hline National Salmon Fjord & County & $\begin{array}{c}\text { Area } \\
\left(\mathrm{km}^{2}\right)\end{array}$ & $\begin{array}{c}\text { Distance to } \\
\text { closest fish } \\
\text { farm }(\mathrm{km})\end{array}$ \\
& & & \\
Trondheimsfjord & Sør Trøndelag & $\mathbf{1 5 2 6 . 4 9}$ & $\mathbf{8 1}$ \\
Tanafjord & Finnmark & 809.92 & nd \\
Svennerbassenget & Telemark & 619.25 & nd \\
Sognefjord & Sogn og Fjordane & $\mathbf{6 1 1 . 0 8}$ & $\mathbf{3 6}$ \\
Coast of Jæren-Dalane & Rogaland & $\mathbf{4 4 5 . 6 1}$ & $\mathbf{5 2}$ \\
Porsangerfjord & Finnmark & $\mathbf{4 2 3 . 5 7}$ & $\mathbf{1 0 8}$ \\
Lindesnes - Mannefjord & Vest Agder & 229.64 & nd \\
Ranafjord & Nordland & 215.32 & nd \\
Namsfjord & Nord Trøndelag & $\mathbf{1 8 3 . 8 7}$ & $\mathbf{2 6 . 5}$ \\
Neidenfjord - Bøkefjord & Finnmark & 177.21 & nd \\
Altafjord & Finnmark & $\mathbf{1 7 4 . 6 9}$ & $\mathbf{1 3}$ \\
Malangen & Troms & 173.42 & nd \\
Reisafjord & Troms & 149.72 & nd \\
Vefsnfjord & Nordland & 142.53 & nd \\
Halsafjord & Møre og Romsdal & 137.46 & nd \\
Sandsfjord & Rogaland & 102.63 & nd \\
Kongsjord & Finnmark & 100.17 & nd \\
Fjords around Osterøy & Hordaland & 66.76 & nd \\
Romsdalsfjord & Møre og Romsdal & $\mathbf{6 5 . 6 6}$ & $\mathbf{8 . 5}$ \\
Sunndalsfjord & Møre og Romsdal & 50.51 & nd \\
Kvænangen & Troms & 42.69 & nd \\
Beiarfjord & Nordland & 38.13 & nd \\
Repparfjord & Finnmark & 36.40 & nd \\
Førdefjord & Sogn og Fjordane & 35.40 & nd \\
Etnefjord - Ølsfjord & Hordaland-Rogaland & $\mathbf{3 1 . 7 9}$ & $\mathbf{1 4}$ \\
Dalsfjord & Sogn og Fjordane & 30.75 & nd \\
Affjord & Sør Trøndelag & 27.27 & nd \\
Nordfjord & Sogn og Fjordane & 23.65 & nd \\
Ørstafjord & Møre og Romsdal & $\mathbf{1 6 . 1 7}$ & $\mathbf{1 1}$ \\
\hline
\end{tabular}

these premises, the risk index proposed by Taranger et al. (2012) and used in the present study conservatively predicts a $100 \%$ increase in mortality risk due to sea lice for fish carrying more than 0.3 lice (all stages) per gram of fish weight, $50 \%$ for fish carrying between 0.2 and 0.3 lice $\mathrm{g}^{-1}$, and $20 \%$ for fish carrying between 0.1 and 0.2 lice $\mathrm{g}^{-1}$. No increased mortality is expected for fish carrying less than 0.1 lice $\mathrm{g}^{-1}$. These limits have been proposed for salmon smolts and sea trout and Arctic charr $<150 \mathrm{~g}$, whereas veteran fish have been given more restrictive ones (Taranger et al. 2012). However, and to avoid a significant reduction in sample sizes, we applied these laxer limits to the whole fish sample, so the estimated population reduction must be understood as a minimum estimation. The total increase in mortality risk due to sea lice in a given sample can then be calculated according to the number of individuals (population $\%$ ) in each infection category. Finally, the expected population reducing effect due to sea lice can be classified as small, medium, and high when the increased mortality risk affects $<10 \%, 10-30 \%$, or $>30 \%$ of the population, respectively (Vitenskapelig råd for lakseforvaltning 2012, in Taranger et al. 2012, 2013). lice on their host fish. Although the pathogenicity of the chalimus stages is considerably smaller than that of the mobile lice, all stages are included in this calculation, in the assumption that all chalimus will reach the pre-adult stage and became pathogenic. Lice mortality close to 0 is thus assumed when developing from chalimus to pre-adult and adult stages. For lice loads over this limit, the consequences of the infection are expected to significantly develop into pathogenicity and ultimately death of the host. It can be conservatively expected that a salmon smolt will have a high probability of mortality when carrying more than 0.3 lice $\mathrm{g}^{-1}$ of fish weight if the lice developed into mobile stages. However, studies addressing direct mortality due to sea lice are scarce, and it has been suggested that wild fish might suffer higher mortalities than those reported by laboratory experiments due to other additive detrimental effects (Ibrahim et al. 2000, Finstad et al. 2007). Under

\section{Fish farming levels and lice of farm origin}

All active salmon farms within a $30 \mathrm{~km}$ sea-way distance from any of the wild sea trout sampling locations included in the national sea lice monitoring program were identified and investigated for monthly standing stock (reported to the Norwegian Directorate of Fisheries, www.fiskeridir.no) and average number of mature female lice fish $^{-1}$ (reported to the Norwegian Food Safety Authority, www.mattilsynet. no, following standardized procedures) between 2010 and 2012. Temperature at $3 \mathrm{~m}$ depth was also reported for every farm on a regular basis and used in the present study. The daily production of infective louse larvae on each investigated farm was calculated according to Stien et al. (2005) as a function of the number of fish in the farm, the average number of adult female lice per fish, and the water temperature as follows: 
(1) The daily per capita production of eggs from female lice was calculated as 300/development time of the eggs. The development time of the eggs (from the formation of the egg strings until the eggs hatch) was determined by the sea temperature and calculated according to the formula: Development time of eggs $=\{42 /[T-10+(42 \times 0.34)]\}^{2}$, where $T$ is water temperature $\left({ }^{\circ} \mathrm{C}\right)$.

(2) The development time from hatched eggs to pre-infective stage was given by the formula:

Development time of pre-infective stages $=\{24.8 /$ $[T-10+(24.8 \times 0.53)]\}^{2}$, where $T$ is water temperature $\left({ }^{\circ} \mathrm{C}\right)$.

(3) The mortality rate from egg to pre-infective stage was set as a constant rate of $17 \% \mathrm{~d}^{-1}$.

(4) The total daily production of infective stages in each farm was finally calculated according to the number of fish in the farm and the average number of female lice on the fish.

\section{Fish farms as a source of lice for wild salmonids}

The relationship between lice abundance on wild sea trout (response variable, $y$ ) and the salmon lice infection pressure (predictor, $x$ ) imposed by nearby farms was investigated using Pearson correlation and linear regression. As the goal was to investigate the role of fish farms as a potential source of lice for wild fish, all sampling locations included in the national sea lice monitoring program situated within a $30 \mathrm{~km}$ distance from the closest active fish farm were included in the analysis, regardless of whether they were situated inside or outside a protected area. Corresponding farm data for all of these fishing locations were only available for 2010 and 2011, and the analysis was therefore restricted to those years. The Pearson correlation coefficient was compared to the robust Spearman rank correlation coefficient to examine the sensitivity of a possible non-normal residual distribution. The basic statistical analyses were performed using both IBM SPSS Statistics 21 and the statistical toolbox in Matlab R2013a by different persons on the 2 platforms. Because 2 to 4 observations of $(x, y)$ at different times were available for each sea trout gill-net location, the Matlab platform was used to run extensive simulations to examine possible pseudoreplicate effects.

An accurate prediction of the spatiotemporal dispersion of planktonic lice larvae from a fish farm can only be achieved by including realistic currents through implementing a reliable distribution and abundance model based on environmental data
(Asplin et al. 2011). However, in general terms it can be expected that the capacity of a fish farm to act as a source of sea lice for a particular sampling location might decrease with increasing distance between them (Gargan et al. 2003, Middlemas et al. 2013). In the absence of detailed lice dispersion models applicable to each particular situation and in order to account to some extent for the effect of distance in the contribution of each farm in terms of infective lice stages for a particular sampling location, a simple 1-parametric down-weighting function was applied using the formula:

$$
N_{\text {lice }}(x)=N_{\text {lice }}(0) \cdot\left[1-\frac{x(\mathrm{~km})}{30}\right]^{\alpha}
$$

i.e. the number of infective sea lice larvae produced in a farm that will potentially reach a sampling location situated at a distance $x$ (in $\mathrm{km}$ ) from it, $0 \leq x \leq$ $30 \mathrm{~km}$, where the parameter $\alpha$ is non-negative.

Three different values of $\alpha$ were examined ( $\alpha=0$, 1 , and 2), and the one that gave the most coherent correspondence between farm lice production and lice infection was selected for further analysis. $\alpha=0$ corresponds to a constant lice level independent of distance from the farms, $\alpha=1$ corresponds to a linear decrease, and $\alpha=2$ corresponds to the fastest decrease with distance, close to an exponential decay. This model is a simplification of the real situation, as it assumes that the influence of a farm situated more than $30 \mathrm{~km}$ away is negligible, and it does not account for local hydrodynamic patterns, but offers an easy way to balance the contribution of close and distant farms to the lice infection pressure in a particular location.

\section{RESULTS}

\section{Salmon lice infection levels on wild sea trout inside 'large' protected areas}

As shown in Fig. 1, the sea trout sampling locations situated inside the 4 biggest National Salmon Fjords investigated (from North to South: Porsangerfjord, Trondheimsfjord, Sognefjord, and Jæren-Dalane) were situated more than $30 \mathrm{~km}$ away from the closest active fish farm between 2008 and 2012; these 4 National Salmon Fjords were therefore defined as 'large' protected areas, and the influence of lice of farm origin in these areas was expected to be small (Gargan et al. 2003, Krkošek et al. 2005, Asplin et al. 2011, Middlemas et al. 2013, Salama et al. 2013). Within the extensive range of sea trout sampling 
locations included in the national sea lice monitoring program, only 1 non-protected location was found to remain more than $30 \mathrm{~km}$ away from any fish farm during the whole period investigated (that at Sandnesfjord, situated $88 \mathrm{~km}$ away from the closest fish farm, data not shown); we decided to include this location under the category of 'large' protected areas in order to add robustness to the analyses.
A total of 857 fish (777 sea trout, 26 Arctic charr, and 54 sea trout or Arctic charr, species not specified) were sampled inside these 'large' protected areas between 2008 and 2012 (Table 2). Data were available from 42 location-year-period combinations with an average of 20 fish per sample (range: 6-39). Of the 857 fish sampled, 598 (70\%) had no lice. Prevalence (percentage of fish with lice) ranged

Table 2. Salmon lice infection parameters for sea trout caught inside large National Salmon Fjords (i.e. $>30 \mathrm{~km}$ from the closest fish farming site) in the period 2008 to 2012 (from north to south). Period: 1 (May to June), 2 (June to August); prevalence: percentage of fish infected in the sample; mean abundance: average number of salmon lice in all sampled fish; mean intensity: average number of salmon lice in infected fish; max.: maximum number of lice recorded on a fish; increase in mortality risk: percentage of the sample estimated to suffer an increase in mortality risk due to sea lice according to Taranger et al. (2012); expected population-reducing effects: classified as 'low', 'medium,' and 'high' according to the percentage of fish in the sample expected to suffer an increase in mortality risk, according to Vitenskapelig råd for lakseforvaltning 2012 (in Taranger et al. 2012, 2013)

\begin{tabular}{|c|c|c|c|c|c|c|c|c|c|c|}
\hline Fjord & Year & Period & $\mathrm{N}$ & $\begin{array}{l}\text { Weight }(\mathrm{g}) \\
\text { mean } \pm \mathrm{SD}\end{array}$ & $\begin{array}{c}\text { Prevalence } \\
(\%)\end{array}$ & $\begin{array}{c}\text { Mean } \\
\text { abundance }\end{array}$ & $\begin{array}{l}\text { Mean } \\
\text { intensity }\end{array}$ & Max. & $\begin{array}{c}\text { Increase in } \\
\text { mortality } \\
\text { risk (\%) }\end{array}$ & $\begin{array}{l}\text { Expected } \\
\text { population- } \\
\text { reducing effect }\end{array}$ \\
\hline Porsangerfjord & $\begin{array}{l}2008 \\
2009 \\
\\
2010 \\
\\
2011\end{array}$ & $\begin{array}{l}1 \\
1 \\
2 \\
1 \\
2 \\
1 \\
2\end{array}$ & $\begin{array}{l}16 \\
28 \\
26 \\
34 \\
22 \\
22 \\
13\end{array}$ & $\begin{array}{l}326.3 \pm 359.1 \\
269.3 \pm 219.6 \\
160.8 \pm 175.0 \\
235.8 \pm 171.7 \\
243.8 \pm 320.2 \\
157.1 \pm 67.4 \\
411.5 \pm 658.5\end{array}$ & $\begin{array}{c}6.3 \\
7.1 \\
23.1 \\
23.5 \\
54.5 \\
0 \\
15.4\end{array}$ & $\begin{array}{l}0.3 \\
0.1 \\
0.5 \\
0.3 \\
0.8 \\
0.0 \\
0.2\end{array}$ & $\begin{array}{c}4 \\
1 \\
2.2 \\
1.3 \\
1.5 \\
0 \\
1\end{array}$ & $\begin{array}{l}4 \\
1 \\
4 \\
2 \\
3 \\
0 \\
1\end{array}$ & $\begin{array}{l}0.00 \\
0.00 \\
0.00 \\
0.00 \\
0.00 \\
0.00 \\
0.00\end{array}$ & $\begin{array}{l}\text { Low } \\
\text { Low } \\
\text { Low } \\
\text { Low } \\
\text { Low } \\
\text { Low } \\
\text { Low }\end{array}$ \\
\hline Trondheimsfjord & $\begin{array}{l}2008 \\
2009 \\
2010 \\
2011 \\
2012\end{array}$ & $\begin{array}{l}1 \\
2 \\
1 \\
2 \\
1 \\
2 \\
1 \\
2 \\
1 \\
2\end{array}$ & $\begin{array}{c}25 \\
24 \\
21 \\
9 \\
9 \\
20 \\
31 \\
25 \\
28 \\
25\end{array}$ & $\begin{array}{l}130.7 \pm 77.84 \\
274.4 \pm 157.0 \\
218.9 \pm 148.2 \\
261.6 \pm 193.2 \\
383.6 \pm 256.4 \\
199.1 \pm 245.8 \\
139.6 \pm 96.8 \\
244.5 \pm 237.3 \\
157.3 \pm 151.3 \\
456.8 \pm 414.6\end{array}$ & $\begin{array}{c}0 \\
54.2 \\
33.3 \\
55.6 \\
33.3 \\
5 \\
0 \\
72 \\
28.6 \\
44\end{array}$ & $\begin{array}{l}0.0 \\
2.5 \\
0.4 \\
2.8 \\
4.0 \\
0.2 \\
0.0 \\
8.1 \\
1.9 \\
2.5\end{array}$ & $\begin{array}{c}0 \\
4.5 \\
1.3 \\
5 \\
12 \\
4 \\
0 \\
11.3 \\
6.6 \\
5.7\end{array}$ & $\begin{array}{c}0 \\
12 \\
2 \\
8 \\
29 \\
4 \\
0 \\
44 \\
14 \\
17\end{array}$ & $\begin{array}{l}0.00 \\
0.00 \\
0.00 \\
0.00 \\
2.22 \\
0.00 \\
0.00 \\
6.80 \\
1.43 \\
2.00\end{array}$ & $\begin{array}{l}\text { Low } \\
\text { Low } \\
\text { Low } \\
\text { Low } \\
\text { Low } \\
\text { Low } \\
\text { Low } \\
\text { Low } \\
\text { Low } \\
\text { Low }\end{array}$ \\
\hline Sognefjord & $\begin{array}{l}2008 \\
2009 \\
2010 \\
2011 \\
2012\end{array}$ & $\begin{array}{l}1 \\
2 \\
1 \\
2 \\
1 \\
2 \\
1 \\
2 \\
1 \\
2\end{array}$ & $\begin{array}{l}16 \\
6 \\
21 \\
14 \\
20 \\
17 \\
17 \\
12 \\
15 \\
20\end{array}$ & $\begin{array}{l}162.2 \pm 62.4 \\
237.2 \pm 293.9 \\
132.4 \pm 62.1 \\
238.7 \pm 169.8 \\
158.0 \pm 87.73 \\
183.3 \pm 86.38 \\
237.5 \pm 207.8 \\
202.6 \pm 227.7 \\
319.2 \pm 448.4 \\
165.9 \pm 94.0\end{array}$ & $\begin{array}{c}0 \\
0 \\
71.4 \\
14.3 \\
30 \\
47.1 \\
11.8 \\
0 \\
66.7 \\
55\end{array}$ & $\begin{array}{l}0.0 \\
0.0 \\
3.5 \\
1.1 \\
0.8 \\
1.2 \\
1.2 \\
0.0 \\
3.1 \\
2.9\end{array}$ & $\begin{array}{c}0 \\
0 \\
4.9 \\
8 \\
2.5 \\
2.6 \\
10.5 \\
0 \\
5.8 \\
5.3\end{array}$ & $\begin{array}{c}0 \\
0 \\
14 \\
10 \\
4 \\
8 \\
19 \\
0 \\
17 \\
17\end{array}$ & $\begin{array}{l}0.00 \\
0.00 \\
0.95 \\
0.00 \\
0.00 \\
0.00 \\
0.00 \\
0.00 \\
1.33 \\
2.50\end{array}$ & $\begin{array}{l}\text { Low } \\
\text { Low } \\
\text { Low } \\
\text { Low } \\
\text { Low } \\
\text { Low } \\
\text { Low } \\
\text { Low } \\
\text { Low } \\
\text { Low }\end{array}$ \\
\hline $\begin{array}{l}\text { Coast of Jæren- } \\
\text { Dalane } \\
\text { (Rogaland) }\end{array}$ & $\begin{array}{l}2011 \\
2012\end{array}$ & $\begin{array}{l}1 \\
2 \\
1 \\
2\end{array}$ & $\begin{array}{l}10 \\
16 \\
15 \\
23\end{array}$ & $\begin{array}{l}149.2 \pm 107.2 \\
236.4 \pm 137.0 \\
215.9 \pm 301.4 \\
239.7 \pm 142.7\end{array}$ & $\begin{array}{c}10 \\
50 \\
46.7 \\
82.6\end{array}$ & $\begin{array}{l}0.1 \\
0.7 \\
1.3 \\
2.4\end{array}$ & $\begin{array}{c}1 \\
1.4 \\
2.7 \\
2.9\end{array}$ & $\begin{array}{c}1 \\
3 \\
9 \\
15\end{array}$ & $\begin{array}{l}0.00 \\
0.00 \\
0.00 \\
0.00\end{array}$ & $\begin{array}{l}\text { Low } \\
\text { Low } \\
\text { Low } \\
\text { Low }\end{array}$ \\
\hline Sandnesfjord & $\begin{array}{l}2008 \\
2009 \\
2010 \\
2011 \\
2012\end{array}$ & $\begin{array}{l}1 \\
2 \\
1 \\
2 \\
1 \\
2 \\
1 \\
2 \\
1 \\
2\end{array}$ & $\begin{array}{l}21 \\
24 \\
23 \\
19 \\
24 \\
21 \\
25 \\
25 \\
14 \\
22\end{array}$ & $\begin{array}{l}284.0 \pm 158.0 \\
313.6 \pm 345.2 \\
217.3 \pm 115.6 \\
158.5 \pm 112.5 \\
243.4 \pm 123.0 \\
231.5 \pm 197.4 \\
178.0 \pm 131.4 \\
171.4 \pm 214.1 \\
199.3 \pm 107.7 \\
311.7 \pm 221.9\end{array}$ & $\begin{array}{c}0 \\
0 \\
13 \\
57.9 \\
12.5 \\
19 \\
12 \\
64 \\
21.4 \\
63.6\end{array}$ & $\begin{array}{l}0.0 \\
0.0 \\
0.1 \\
1.2 \\
0.2 \\
0.5 \\
0.2 \\
2.5 \\
0.2 \\
2.0\end{array}$ & $\begin{array}{c}0 \\
0 \\
1 \\
2 \\
1.7 \\
2.5 \\
1.3 \\
3.9 \\
1 \\
3.1\end{array}$ & $\begin{array}{c}0 \\
0 \\
1 \\
3 \\
3 \\
3 \\
2 \\
10 \\
1 \\
11\end{array}$ & $\begin{array}{l}0.00 \\
0.00 \\
0.00 \\
0.00 \\
0.00 \\
0.00 \\
0.00 \\
0.00 \\
0.00 \\
1.82\end{array}$ & $\begin{array}{l}\text { Low } \\
\text { Low } \\
\text { Low } \\
\text { Low } \\
\text { Low } \\
\text { Low } \\
\text { Low } \\
\text { Low } \\
\text { Low } \\
\text { Low }\end{array}$ \\
\hline
\end{tabular}


from 0 up to $83 \%$ and remained under $50 \%$ on 30 of the 42 sampling occasions $(71 \%)$. Mean intensity (number of lice on infected fish) was low in all of the samples, exceeding 10 lice fish $^{-1}$ only in exceptional cases. The population-reducing effect due to salmon lice infection was estimated as 'low' in $100 \%$ of these samples, with an expected population reduction of $0 \%$ in more than $80 \%$ of the cases.

\section{Salmon lice infection levels on wild sea trout inside 'small' protected areas}

A total of 1268 wild fish (1199 sea trout, 25 Arctic charr, and 44 sea trout or Arctic charr, species not specified) were sampled in the 5 smaller National Salmon Fjords (i.e. those with relevant sampling locations situated $<30 \mathrm{~km}$ away from at least 1 active farm; Table 3). Data were available from 43 loca-

Table 3. Salmon lice infection parameters for sea trout caught inside smaller National Salmon Fjords (i.e. $<30 \mathrm{~km}$ to the closest fish farming site) in the period 2008 to 2012 (from north to south). See Table 2 for details

\begin{tabular}{|c|c|c|c|c|c|c|c|c|c|c|}
\hline Fjord & Year & Period & $\mathrm{N}$ & $\begin{array}{l}\text { Weight }(g) \\
\text { mean } \pm \mathrm{SD}\end{array}$ & Prevalence & $\begin{array}{c}\text { Mean } \\
\text { abundance }\end{array}$ & $\begin{array}{l}\text { Mea } \\
\text { intensity }\end{array}$ & Max. & $\begin{array}{c}\text { Increase in } \\
\text { mortality } \\
\text { risk (\%) }\end{array}$ & $\begin{array}{c}\text { Expected } \\
\text { population- } \\
\text { reducing effect }\end{array}$ \\
\hline Altafjord & $\begin{array}{l}2008 \\
2009 \\
2010 \\
2011 \\
2012\end{array}$ & $\begin{array}{l}1 \\
2 \\
1 \\
2 \\
1 \\
2 \\
1 \\
2 \\
1 \\
2\end{array}$ & $\begin{array}{l}24 \\
24 \\
18 \\
26 \\
20 \\
22 \\
40 \\
23 \\
20 \\
19\end{array}$ & $\begin{array}{l}152.0 \pm 135.4 \\
196.7 \pm 149.4 \\
402.7 \pm 540.9 \\
469.1 \pm 341.3 \\
420.6 \pm 512.2 \\
231.5 \pm 244.1 \\
170.4 \pm 412.1 \\
386.2 \pm 385.2 \\
617.9 \pm 488.5 \\
822.7 \pm 552.6\end{array}$ & $\begin{array}{c}0.0 \\
54.2 \\
38.9 \\
53.9 \\
70.00 \\
68.2 \\
0.0 \\
82.6 \\
20.0 \\
73.7\end{array}$ & $\begin{array}{c}0.0 \\
1.5 \\
0.7 \\
1.0 \\
3.1 \\
4.3 \\
0.0 \\
24.8 \\
0.6 \\
9.2\end{array}$ & $\begin{array}{c}- \\
2.8 \\
1.9 \\
1.8 \\
4.4 \\
6.3 \\
- \\
30 \\
2.8 \\
12.4\end{array}$ & $\begin{array}{c}0 \\
13 \\
3 \\
3 \\
13 \\
52 \\
0 \\
73 \\
6 \\
27\end{array}$ & $\begin{array}{c}0.00 \\
0.00 \\
0.00 \\
0.00 \\
0.00 \\
0.00 \\
0.00 \\
23.91 \\
0.00 \\
0.00\end{array}$ & $\begin{array}{c}\text { Low } \\
\text { Low } \\
\text { Low } \\
\text { Low } \\
\text { Low } \\
\text { Low } \\
\text { Low } \\
\text { Medium } \\
\text { Low } \\
\text { Low }\end{array}$ \\
\hline Namsfjord & $\begin{array}{l}2009 \\
2010 \\
2011 \\
2012\end{array}$ & $\begin{array}{l}1 \\
2 \\
1 \\
2 \\
1 \\
2 \\
1 \\
2\end{array}$ & $\begin{array}{l}21 \\
22 \\
21 \\
16 \\
20 \\
36 \\
26 \\
18\end{array}$ & $\begin{array}{l}483.1 \pm 176.4 \\
259.1 \pm 199.3 \\
409.0 \pm 370.5 \\
391.7 \pm 345.7 \\
422.3 \pm 360.1 \\
138.7 \pm 71.4 \\
173.8 \pm 105 \\
272.0 \pm 168.6\end{array}$ & $\begin{array}{c}0.0 \\
36.4 \\
0.0 \\
31.3 \\
25.0 \\
69.4 \\
0.0 \\
38.9\end{array}$ & $\begin{array}{c}0.0 \\
0.7 \\
0.0 \\
1.9 \\
2.1 \\
12.6 \\
0.0 \\
8.2\end{array}$ & $\begin{array}{c}- \\
1.9 \\
- \\
6.2 \\
8.4 \\
18.1 \\
- \\
21.0\end{array}$ & $\begin{array}{c}0 \\
4 \\
0 \\
13 \\
18 \\
157 \\
0 \\
69\end{array}$ & $\begin{array}{c}0.00 \\
0.00 \\
0.00 \\
0.00 \\
0.00 \\
8.89 \\
0.00 \\
12.22\end{array}$ & $\begin{array}{c}\text { Low } \\
\text { Low } \\
\text { Low } \\
\text { Low } \\
\text { Low } \\
\text { Low } \\
\text { Low } \\
\text { Medium }\end{array}$ \\
\hline Romsdaslfjord & $\begin{array}{l}2008 \\
2009 \\
2010 \\
2011 \\
2012\end{array}$ & $\begin{array}{l}1 \\
2 \\
1 \\
2 \\
1 \\
2 \\
1 \\
2 \\
1 \\
2\end{array}$ & $\begin{array}{c}8 \\
24 \\
22 \\
21 \\
20 \\
18 \\
31 \\
26 \\
23 \\
22\end{array}$ & $\begin{array}{l}645.5 \pm 472.0 \\
145.4 \pm 179.4 \\
113.2 \pm 133.2 \\
422.5 \pm 511.1 \\
272.5 \pm 250.1 \\
160.5 \pm 120.4 \\
161.0 \pm 163.1 \\
150.5 \pm 98.9 \\
136.3 \pm 146.3 \\
203.4 \pm 303.4\end{array}$ & $\begin{array}{l}50.0 \\
83.3 \\
68.2 \\
85.7 \\
30.0 \\
33.3 \\
19.4 \\
46.1 \\
39.1 \\
68.2\end{array}$ & $\begin{array}{c}1.6 \\
16.2 \\
2.9 \\
6.7 \\
1.3 \\
4.2 \\
0.4 \\
8.5 \\
1.1 \\
12.5\end{array}$ & $\begin{array}{c}3.3 \\
19.5 \\
4.3 \\
7.8 \\
4.3 \\
12.5 \\
2 \\
18.3 \\
2.8 \\
18.4\end{array}$ & $\begin{array}{c}8 \\
86 \\
14 \\
28 \\
12 \\
54 \\
3 \\
68 \\
7 \\
55\end{array}$ & $\begin{array}{c}0.00 \\
20.00 \\
0.00 \\
2.86 \\
0.00 \\
5.56 \\
0.00 \\
9.62 \\
0.00 \\
15.45\end{array}$ & $\begin{array}{c}\text { Low } \\
\text { Medium } \\
\text { Low } \\
\text { Low } \\
\text { Low } \\
\text { Low } \\
\text { Low } \\
\text { Low } \\
\text { Low } \\
\text { Medium }\end{array}$ \\
\hline $\begin{array}{l}\text { Ørstafjord } \\
\text { (Storfjord) }\end{array}$ & $\begin{array}{l}2010 \\
2011 \\
2012\end{array}$ & $\begin{array}{l}1 \\
2 \\
1 \\
2 \\
1 \\
2\end{array}$ & $\begin{array}{c}4 \\
20 \\
22 \\
28 \\
21 \\
22\end{array}$ & $\begin{aligned} 97.5 & \pm 24.1 \\
239.5 & \pm 181.8 \\
235.0 & \pm 225.6 \\
203.1 & \pm 203.4 \\
116.1 & \pm 82.7 \\
243.8 & \pm 319.8\end{aligned}$ & $\begin{array}{c}50.0 \\
90.0 \\
68.2 \\
100.0 \\
33.3 \\
63.6\end{array}$ & $\begin{array}{c}1.0 \\
21.7 \\
5.7 \\
10.0 \\
17.4 \\
28.1\end{array}$ & $\begin{array}{c}2 \\
24.1 \\
8.4 \\
10 \\
52.3 \\
44.2\end{array}$ & $\begin{array}{c}2 \\
152 \\
38 \\
32 \\
178 \\
152\end{array}$ & $\begin{array}{c}0.00 \\
19.00 \\
2.27 \\
7.50 \\
19.05 \\
30.45\end{array}$ & $\begin{array}{l}\text { Low } \\
\text { Medium } \\
\text { Low } \\
\text { Low } \\
\text { Medium } \\
\text { High }\end{array}$ \\
\hline $\begin{array}{l}\text { Etnefjord } \\
\text { (Hardangerfjord) }\end{array}$ & $\begin{array}{l}2008 \\
2009 \\
2010 \\
\\
2011\end{array}$ & $\begin{array}{l}1 \\
1 \\
2 \\
1 \\
2 \\
1 \\
2 \\
1 \\
2\end{array}$ & $\begin{array}{c}18 \\
28 \\
24 \\
28 \\
26 \\
22 \\
37 \\
130 \\
120\end{array}$ & $\begin{aligned} 175.3 & \pm 159.8 \\
203.2 & \pm 411.5 \\
148.7 & \pm 78.7 \\
432.5 & \pm 398.1 \\
339.8 & \pm 373.4 \\
94.0 & \pm 44.5 \\
111.9 & \pm 144.3 \\
73.9 & \pm 125.2 \\
84.9 & \pm 139.9\end{aligned}$ & $\begin{array}{c}83.3 \\
46.4 \\
91.7 \\
57.1 \\
92.3 \\
22.7 \\
27.0 \\
50.8 \\
100.0\end{array}$ & $\begin{array}{c}46.3 \\
2.5 \\
25.4 \\
5.2 \\
106.0 \\
1.5 \\
4.3 \\
8.1 \\
88.4\end{array}$ & $\begin{array}{c}55.6 \\
5.4 \\
27.8 \\
9.1 \\
114.8 \\
6.8 \\
15.8 \\
16.0 \\
88.4\end{array}$ & $\begin{array}{c}184 \\
22 \\
128 \\
41 \\
467 \\
22 \\
122 \\
350 \\
689\end{array}$ & $\begin{array}{c}40.55 \\
1.79 \\
30.00 \\
0.00 \\
44.62 \\
0.00 \\
3.24 \\
9.38 \\
89.75\end{array}$ & $\begin{array}{l}\text { High } \\
\text { Low } \\
\text { Medium } \\
\text { Low } \\
\text { High } \\
\text { Low } \\
\text { Low } \\
\text { Low } \\
\text { High }\end{array}$ \\
\hline
\end{tabular}


tion-year-period combinations with an average of 27 fish per sample (range: 4-130). Prevalence in these samples ranged from 0 to $100 \%$, with infection levels generally increasing throughout the summer. In all 5 fjords, peaks of infection were detected at least once during the study period.

Inside the National Salmon Fjord of Altafjord, a peak of infection was detected on wild sea trout in 2011, when $83 \%$ of the fish sampled were infected with 30 lice fish $^{-1}$ on average (mean intensity). In this year, $24 \%$ of the wild sea trout population was estimated to experience an increased mortality risk due to sea lice, resulting in an expected 'medium' population reducing effect. Two peaks of infection were detected in Namsfjord in 2011 and 2010, when approximately 9 and $12 \%$ of the fish were estimated to experience an increased mortality risk due to sea lice, respectively. In Romsdalsfjord, peaks of infection were observed throughout the $5 \mathrm{yr}$ investigation period. In 2008, high prevalence (80\%) was accompanied by a mean intensity of approximately 19 lice per infected fish, and $20 \%$ of the sampled fish were estimated to experience an increase in mortality risk due to lice. Between 2010 and 2012, lice levels on wild sea trout seemed to progressively increase in Romsdalsfjord, especially during mid-summer (period 2 ), and the risk for population-reducing effects due to sea lice reached the category of 'medium' in 2012.

Higher lice loads were recorded on wild sea trout in the National Salmon Fjords of Etnefjord (located in Hardangerfjord) and Ørstafjord (located in Storfjord), the smallest protected areas investigated. In Ørstafjord, peaks of infection were repeatedly detected in the 3 years investigated. In 2010, $90 \%$ of the wild sea trout caught inside this protected area were infected with an average of 24 lice fish ${ }^{-1}$ (mean intensity), and $19 \%$ of these fish were expected to experience an increased mortality risk due to sea lice ('medium' risk for population-reducing effects). The highest infection level detected in this fjord occurred in 2012. Already in early summer (period 1), onethird of the wild sea trout were infected with an average of more than 55 lice fish $^{-1}$ (mean intensity), and an increased risk of mortality due to the infection was expected for $19 \%$ of the sample. Later that summer (period 2), prevalence had increased to over 63\% while mean intensity remained considerably high (44 lice per infected fish), resulting in an expected 'high' risk for population-reducing effects due to lice.

In Etnefjord (Hardangerfjord), on the other hand, peaks of infections were detected on wild sea trout in all years investigated with the only exception being 2011. In 2008, lice levels were already high during early summer (period 1), and more than $40 \%$ of the sampled fish were expected to experience an increased mortality due to the lice infection ('high' risk of population-reducing effects). In 2009, a new peak of infection was detected, with more than $92 \%$ of the wild fish being infected with an average of 28 lice fish $^{-1}$ (mean intensity) and $30 \%$ of the sample expected to experience increased mortality. In 2010 and 2012, prevalences between 92 and $100 \%$ were recorded together with mean intensities of 114 and 88 lice ish $^{-1}$, respectively. In these years, more than $25 \%$ of the wild fish sampled during the summer (period 2) had 100 or more lice. The risk for population-reducing effects was regarded as 'high' both in 2010 and 2012, with an increased risk of mortality affecting 45 and $90 \%$ of the sampled fish, respectively. In 2011, on the other hand, lice levels recorded on wild sea trout remained substantially lower in Etnefjord, with a recorded prevalence under 30\% and low mean intensity.

\section{Production levels in surrounding fish farms}

All farms situated within a $30 \mathrm{~km}$ range from any of the National Salmon Fjords investigated are shown in Fig. 1. As shown in the figure, none of these farms was located inside the limits of the protected fjords. Fig. 2a shows the total biomass of farmed fish held in sea cages within a $30 \mathrm{~km}$ range from the sampling locations in Altafjord, Namsfjord, Romsdalsfjord, Ørstafjord, and Etnefjord for the period 2010 to 2012. Between 2000 and 7000 t of farmed fish were held in sea cages within a $30 \mathrm{~km}$ range of both Altafjord and Romsdalsfjord during the $3 \mathrm{yr}$ period, with highest biomasses during autumn and winter. In Romsdalsfjord, a slow but progressive increase in farmed biomass was observed between 2010 and 2012. In the other 3 fjords investigated (Namsfjord, Ørstafjord, and Etnefjord), the biomass of farmed fish varied strongly between years as a result of the synchronized fallowing of the farms in these areas during the study period (Taranger et al. 2013). In Namsfjord, all farms situated within $30 \mathrm{~km}$ of the corresponding sampling location (see Fig. 1) were empty until June 2010, when they were re-stocked with fish. From this time, the stocked biomass started increasing rapidly; by June 2011 it had increased to $5000 \mathrm{t}$, and reached up to $15000 \mathrm{t}$ by the end of the year before slowly decreasing again down to 0 by early summer 2012. A strong variation in stocked biomass was also observed in Ørstafjord. Highest biomasses in this area were reported around January 2010 and 2012 (with 

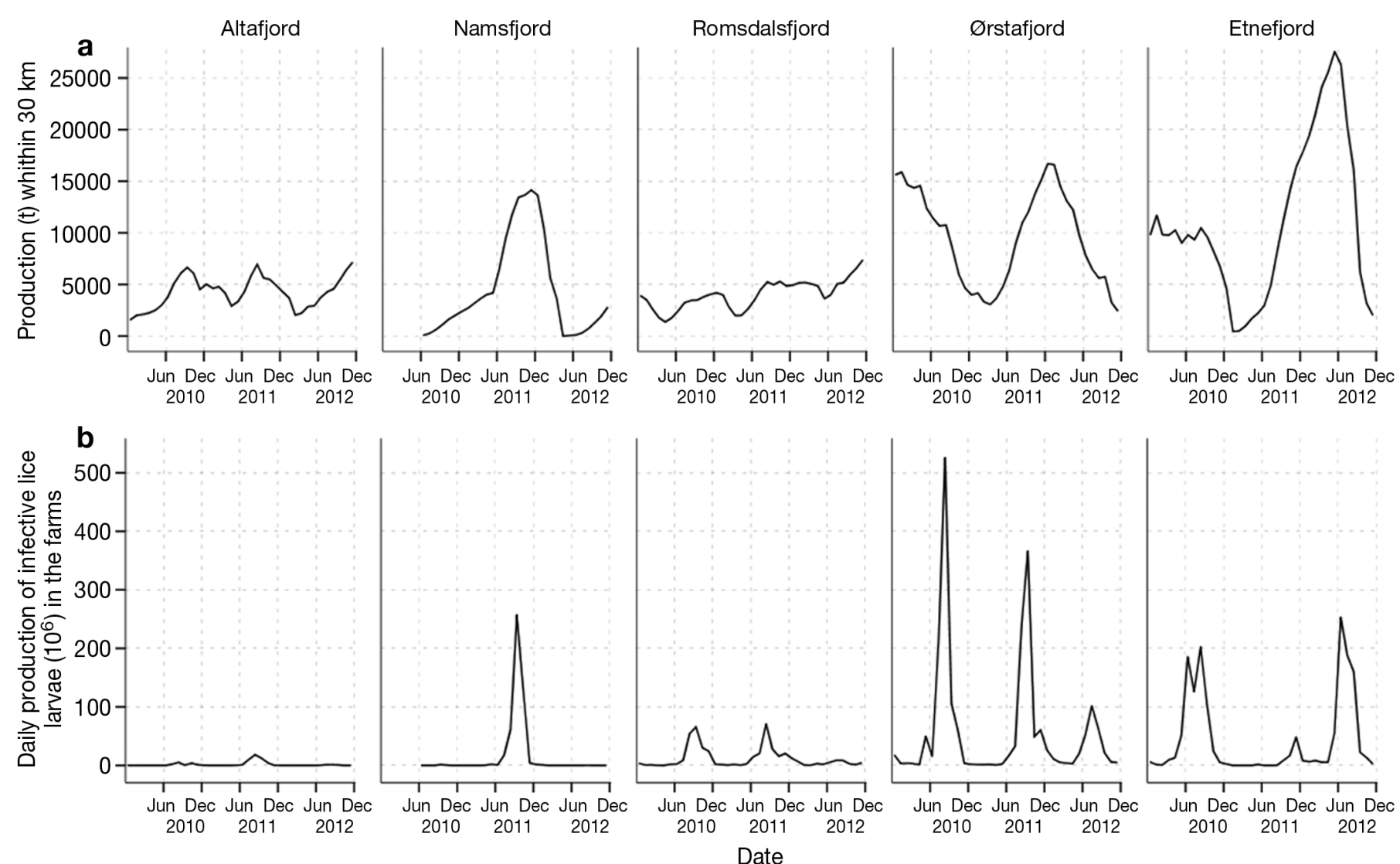

Fig. 2. Production data collected from every salmon and trout farming site situated within $30 \mathrm{~km}$ of relevant sea trout sampling locations (inside National Salmon Fjords) between January 2010 and December 2012. (a) Accumulated stocked biomass (t), based on official data reported to the Norwegian Directorate of Fisheries (www.fiskeridir.no). (b) Accumulated daily production of infective lice larvae (calculated according to Stien et al. 2005 and based on lice counts reported to the Norwegian Food Safety Authorities, www.mattilsynet.no)

approximately $15000 \mathrm{t}$ of stocked fish), with a substantially lower stocked biomass reported in January 2011 (around 4000 t). A similar pattern was observed in Etnefjord, where the accumulated farmed fish biomass rapidly decreased from $10000 \mathrm{t}$ stocked in 2010 down to 0 at the beginning of 2011 and then progressively increasing again until reaching over $25000 \mathrm{t}$ by the summer of 2012 .

Fig. $2 \mathrm{~b}$ shows the accumulated daily production of infective salmon lice in the farms in the same period. As shown in the figure, peaks of lice production were often detected during late summer and autumn, and remained close to 0 during the rest of the years in most of the cases. While the production of lice of farm origin remained fairly stable and low in both Altafjord and Romsdalsfjord during the $3 \mathrm{yr}$ period (with only 2 small peaks of production in autumn 2010 and 2011 in Romsdalsfjord), it oscillated strongly between years in the other 3 fjords investigated. In Namsfjord, no lice were produced in the farms during 2010 and the first part of 2011.
From August to September 2011, the production of lice in these farms experienced a clear peak and reached a daily production of more than 250 million infective larvae, again decreasing to 0 by December that year and throughout 2012. In Ørstafjord, high peaks of lice production were repeatedly observed in late summer over the 3 yr. In 2010, all farms within $30 \mathrm{~km}$ of the sampling location accumulated a daily production of more than 500 million lice larvae. A similar peak was observed in 2011, when daily production of lice larvae in August and September reached 350 million. In 2012, the production of lice peaked again in late summer, but at a considerably lower level (up to a daily production of 100 million larvae). In the last protected area investigated, Etnefjord, 2 clear peaks of lice production were observed, in 2010 and 2012. In both cases, the production of lice already started increasing in June and reached daily productions of more than 200 million infective larvae. No lice were produced in this area during the summer 2011. 


\section{Relationship between lice of farm origin and infection on wild fish}

In the presence of 1 or more salmon farms within a $30 \mathrm{~km}$ distance, the mean abundance of lice infecting wild sea trout (fish infection henceforth) shows a positive correlation with the accumulated daily production of infective lice stages in the farms during that month (farm production henceforth), on a log-log scale (Fig. 3). The linear regression is based on sea lice counts performed on 1688 sea trout caught with gill nets all along the Norwegian coast in a total of 69 sampling points between 2010 and 2011 (on average 25 fish sample $\left.{ }^{-1}\right)$. Each of the 69 total $(x, y)$ pairs in the figure corresponds to fish infection, $y$, from 1 location in 1 year (2010 or 2011) and 1 period (maximum 4 replicates per location), with the corresponding farm production at that time. The linear downweighting function $(\alpha=1)$ of farm production with distance was chosen, as this choice gave a better model fit than the alternatives $\alpha=0$ and $\alpha=2$ (data not shown). The squared Pearson correlation coefficient was $r^{2}=$ $0.639^{2}=0.409$ (log-transformed data). The Spearman correlation coefficient was 0.618 , thus it is reasonable to assume a negligible impact on the results from a possible deviation from normally distributed residuals.

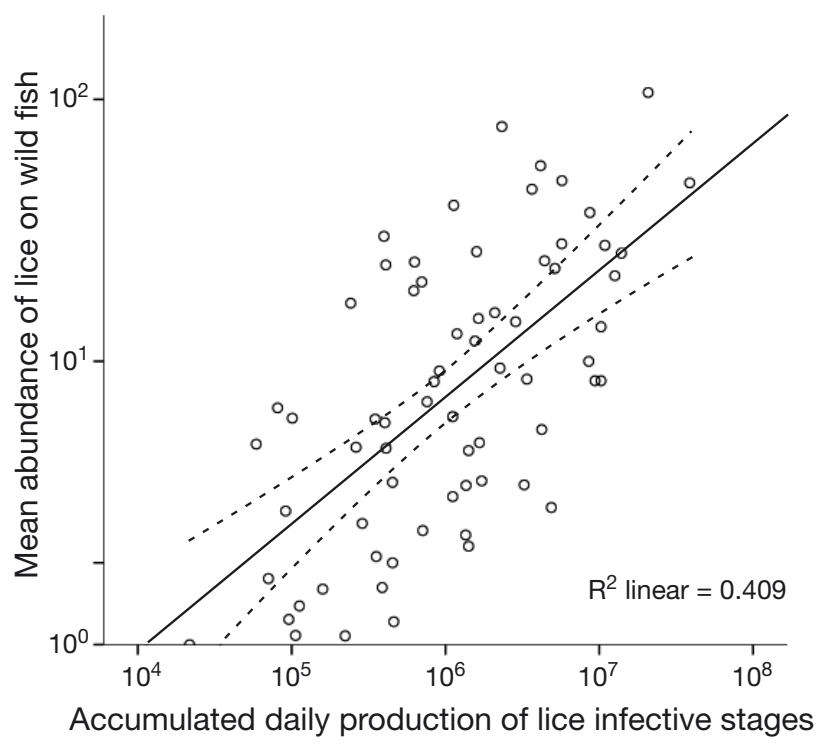

Fig. 3. Linear regression (with 95\% confidence interval, dashed lines) between sea lice infection levels (mean abundance) on wild sea trout and estimated number of infective lice stages produced in nearby farms $\left(\mathrm{r}^{2}=0.409, \mathrm{p}<0.001\right.$, $\mathrm{n}=71$ ). Only farms within $30 \mathrm{~km}$ sea-way distance of the sampling locations are included; a simple linear downweighting was applied to the daily production of lice at each farm to account for the distance to the corresponding sea trout sampling locations
Based on the log-transformed data and standard linear regression analysis, the slope $b$ was significantly greater than 0 and significantly less than 1 at a $5 \%$ significance level, i.e. the result indicates a significantly slower increase in wild fish infection (mean abundance) by farm production than predicted by a linear model, within the range of farm production data. A plot of residuals versus $x$ was used to confirm the assumption of independent and normally distributed residuals with variance independent of $x$ (homoscedasticity).

Possible pseudo-replicate effects were ruled out by comparing the global residual variance with the variance of the residuals at each of the 20 different locations where at least 2 replicates (maximum 4 ) were available. To examine whether the slope, $b$, varied significantly between the 4 different sampling periods involved (2010 and 2011, period 1 and 2), the data were divided in the corresponding 4 subsets. The 4 estimated $b$-values varied from 0.162 to 0.565 with an empirical variance of the 4 values equal to 0.0308 . To investigate whether this variance was larger than expected if the true slopes were equal, 10000 simulations were run with the original regression line and $x$-values treated as true values, with random residuals generated from a 0 -mean normal distribution with variance equal to the estimated residual variance. For each simulation, the 4 slopes and their variance were calculated. To examine the effect of possible deviations from normally distributed residuals, the same exercise was done by bootstrapping the empirical residuals. Both approaches gave very similar results, and the hypothesis of no difference between the 4 slopes was not rejected on a $5 \%$ significance level, with a p-value of ca. $35 \%$.

In conclusion, results from this analysis support the hypothesis of a positive correlation between the production of lice infective stages from fish farms and the mean abundance of lice on wild fish in surrounding areas and suggest that, in areas where active fish farms exist within a distance $<30 \mathrm{~km}$, approximately $41 \%$ of the variance of the mean lice abundance on wild fish (log-transformed data) can be explained by the production of lice in the farms, according to the simple linear model.

\section{DISCUSSION}

Area protection is one of the main strategies adopted by Norwegian authorities to protect local populations of Atlantic salmon, sea trout, and Arctic charr from harmful salmon lice infections derived 
from aquaculture activities (Aasetre \& Vik 2013). Within a National Salmon Fjord, the strict limitations imposed on fish farming activities (NOU 1999, Heuch et al. 2005, DKMD 2006) are presumed to minimize lice production inside the limits of the protected areas. However, the production of planktonic lice larvae from farms situated outside these limits or from the few farms still allowed inside the protected areas, and their transport into the National Salmon Fjords, might still be an important source of lice for local populations of wild salmonids (Taranger et al. 2013), especially in the case of small protected areas and/or in areas of intensive farming (Bjørn et al. 2011). The present study provides a mid-term evaluation, based on results from 9 out of 29 Norwegian National Salmon Fjords, of area protection as a tool to protect wild salmonids against lice of farm origin. A final evaluation is to be done by 2017 .

Results from the present study indicate that the distance to surrounding fish farms plays a key role in the success of the protected salmon fjords. Sea lice levels found on wild sea trout caught inside large protected areas (i.e. where the distance to the closest fish farm was $>30 \mathrm{~km}$ ) such as Porsangerfjord in the north, Trondheimsfjord in the center, and the coast of Jæren-Dalane and Sognefjord in the south of Norway were consistently low over time, presumably having little effect on local populations of wild salmonids. These lice loads were consistent with those reported in other farm-free areas in both northern (Bjørn \& Finstad 2002, Rikardsen 2004) and southern (Mo \& Heuch 1998, Schram et al. 1998) Norway and represent a natural lice-host interaction, characterized by occasionally high prevalence but low mean intensity (Tingley et al. 1997). In the presence of 1 or more salmon farms within a $30 \mathrm{~km}$ distance, on the other hand, mean abundance of lice infecting wild sea trout showed a positive correlation (although increasing slower than predicted by the linear model) with the accumulated daily production of infective lice larvae in the neighboring farms, and approximately $41 \%$ of the variation in mean lice abundance on wild fish could be explained by the production of lice in the farms. This regression analysis was based on sea lice counts on sea trout caught with gill nets all along the Norwegian coast, providing a wide geographical and temporal scale and covering a wide range of environmental scenarios, including areas with both low and high farming intensities.

A clear example of this is shown from the 2 smallest National Salmon Fjords investigated in this study, Ørstafjord (in Storfjord) and Etnefjord (in Hardangerfjord). These 2 particular National Salmon Fjords are not only of rather small size but they are also situated in areas of intensive farming activity, with the distance between the correspondent sea trout sampling locations and the closest fish farms being less than $15 \mathrm{~km}$ in both cases. Lice burdens on wild sea trout caught inside these protected areas were found to be very high during most of the period investigated, and 'medium' to 'high' risk levels for population-reducing effects (Taranger et al. 2012) were often recorded on wild sea trout sampled inside these fjords. These infection levels matched and even exceed those previously reported in areas of intensive farming in Norway (Birkeland 1996, Bjørn et al. 2001, 2011), suggesting that the established area protection is insufficient to provide the desired effect. These results are in accordance with a previous study (Bjørn et al. 2011) where salmon lice infection levels in both wild sea trout and hatchery-reared Atlantic salmon smolts (in sentinel cages) in the Romsdalsfjord were investigated. In that study, the infection levels recorded inside the protected zone (Isfjord) were higher compared to farm-free fjords in Norway, which led the authors to conclude that the protected area was too small to have the necessary protective effect. In addition, lice burdens on wild sea trout caught inside the smallest protected areas investigated in our study (Etnefjord and Ørstafjord) showed strong variations between years, with lice levels oscillating in accordance with the huge variations in stocked biomass in the surrounding farms. These results provide further evidence of even distant farms acting as sources of lice in an area, in agreement with previous studies showing that in areas of intensive salmon farming, sea lice of farm origin are a main source of infection not only for wild salmonids (Bjørn \& Finstad 2002, Gargan et al. 2003, Heuch et al. 2005, Krkošek et al. 2006, Marty et al. 2010), but also for other farmed salmonids (Jansen et al. 2012). Highest infection levels often occur nearest fish farms (Bjørn et al. 2001, Butler \& Watt 2003, Gargan et al. 2003), but lice infective stages can also be dispersed over long distances (Heuch et al. 2005, Stien et al. 2005, Asplin et al. 2011) minimizing the effect of the protective zone. Thus, establishment of small protective zones inside a fjord area or a fjord system can be expected to have limited effects in preventing the transmission of salmon lice from fish farms (Bjørn et al. 2011) and cannot be the only consensus tool used.

Less obvious was the connection between farming activity and lice infection on wild sea trout caught in medium-size protected areas in the present study, such as Altafjord, Namsfjord, and Romsdalsfjord. 
Lice levels reported on wild fish caught inside these protected areas were comparable to those observed in farm-free areas during most of the period evaluated. Peaks of infection were observed in Altafjord in 2011 and in Namsfjord and Romsdalsfjord in 2012. During those periods, the lice production in the surrounding farms was considerably low, thus the high lice loads detected on the wild fish must have been a consequence of additional biological and/or environmental factors. The low water temperatures typically found in northern fjords can extend the development time of the lice, allowing the planktonic lice larvae to disperse over longer distances. A strong in-going current pattern could also result in the lice being transported longer distances (Taranger et al. 2013), thus allowing farms situated more than $30 \mathrm{~km}$ away to act as sources of lice for a particular location.

Hence the importance of a correct design when planning the establishment of a protected area is clear. Given our results, it can be assumed that the outer part of a National Salmon Fjord (from the border and inwards toward the protected area) will act as a 'buffer zone' for the arrival of lice originating from surrounding fish farms. The capacity of these farms to act as a source of lice for wild populations of sea trout and Arctic charr inside the National Salmon Fjords can be expected to progressively decrease as one moves into the protected area and to occasionally disappear when a sufficient distance is reached. Only the area behind this 'buffer zone' (calculated here to extend for approximately $30 \mathrm{~km}$ but expected to be highly site-dependent) can be assumed to remain safe from the potential impact of lice of farm origin and can be considered as truly protected. Both size and shape are therefore of key importance for the optimal design of a National Salmon Fjord, and the final success of these protected areas ultimately depends on their capacity to keep fish farms at a sufficient distance. A key factor for the optimal design of a protected salmon fjord is thus the correct determination of what can be considered a sufficient distance, for which purpose a good understanding of the distribution and abundance of sea lice larvae in the natural environment is required. The development of coupled biological-hydrodynamic lice dispersion models has become widespread in the last $10 \mathrm{yr}$. These kinds of models require detailed information about water currents in time and space in the study areas. Such information can be obtained from 3dimensional current models using a sufficiently detailed and realistic set of forcing and boundary values. Often it will be necessary to use several models to model fjord currents correctly, e.g. a separate high-resolution atmosphere model and a coastal ocean model (Asplin et al. 2011). Lice spread was simulated in the Sognefjord in the first half of 2000 (Asplin et al. 2004). Similar studies have also been conducted in Scotland (Gillibrand \& Willis 2007) and in many salmon-producing countries (Amundrud \& Murray 2009, Asplin et al. 2011, Johnsen 2011, Stucchi et al. 2011, Taranger et al. 2013), and international collaboration that seeks to enhance our understanding about dispersion modeling of sea lice is currently ongoing. These kinds of models may eventually provide the basis for more precise management practices of lice in fish farms throughout the Norwegian coast.

One of the main objectives with the establishment of the National Salmon Fjords is the protection of important Atlantic salmon populations. Unfortunately, sampling Atlantic salmon post-smolts at sea is difficult and costly (Finstad et al. 2000, 2005, Bjørn et al. 2007); for this reason, sea lice counts performed on wild sea trout and Arctic charr have been commonly used to monitor sea lice infection pressure in littoral areas and are used in the present study to evaluate the effectiveness of the National Salmon Fjords. However, the benefits of area protection might not be the same for both species due to significant behavioral differences. While sea trout and Arctic charr tend to spend most of their sea-phase in littoral areas within a few kilometers of their native rivers (Jensen 1968, Berg \& Berg 1987, Thorstad et al. 2004, 2007, Finstad et al. 2005), a wild Atlantic salmon post-smolt may use ca. 14 to $30 \mathrm{~d}$ to migrate from the innermost part of a large fjord (as the Hardangerfjord) to the open sea (Vitenskapelig råd for lakseforvaltning 2011) and might therefore be exposed to different infection pressures along their journey throughout the fjord (Thorstad et al. 2004, Finstad et al. 2005, Davidsen et al. 2008). The establishment of a protected area inside a fjord system might thus benefit local populations of wild sea trout and Arctic charr to a certain degree, but the benefits for wild Atlantic salmon post-smolts will strongly depend on the infection pressure in other parts of the fjord (Heuch \& Mo 2001) and the time the fish are exposed to infective lice larvae in these areas (Sivertsgård et al. 2007). Since the size of the protected areas is limited and they rarely cover the whole length of a fjord system, this cannot be the only tool used to protect wild salmonids against the transmission of salmon lice from fish farms. The implementation of additional management strategies such as the regionalized and synchronized delousing/fallowing of farms inside the entire fjord system (Heuch et al. 2005), the compul- 
sory reporting of louse counts (NOU 1999), lower legal maximums for the mean number of lice per farmed fish (Heuch \& Mo 2001), or even a reduction in the maximum allowed stocked biomass is probably necessary to reduce lice infection levels on wild salmonids to sustainable levels.

In summary, results from the present study indicate that the Norwegian National Salmon Fjords may provide a certain extent of protection against lice of farm origin when the size and shape of the protected area ensure a minimum distance to the surrounding fish farms. The effects of small National Salmon Fjords, on the other hand, can be expected to strongly depend on the production pattern of the aquaculture industry in the surrounding area both as a function of biomass but especially as a function of the number of lice produced in the nearby farm sites, indicating that the degree of protection in these cases is questionable. Although individual study of each National Salmon Fjord may be necessary to evaluate the degree of protection, one can expect that the capacities of the smallest fjords of withstanding lice infection from fish farms are probably limited. It is therefore reasonable to assume that the protection of large areas contributes best to ensure the protection of wild salmon. In order to establish more precise management practices, both in National Salmon Fjords and other fjord systems throughout the Norwegian coast, the development and validation of accurate planktonic larval distribution and abundance models is needed. If one could predict the abundance and distribution of lice from fish farms in time and space by use of hydrodynamic models (Asplin et al. 2011) on one hand and determine the critical abundance threshold for effects on wild salmonid populations according to politically specific sustainability goals on the other hand, this could be the basis for an area management system based on 'maximum sustainable lice loads' or 'lice quotas.'

Acknowledgements. This study was funded by the Norwegian Food Safety Authority, the Institute of Marine Research, and the Norwegian Institute for Nature Research. We are grateful to all field personnel which helped perform the field work and to the aquaculture industry, the Norwegian Food Safety Authority, and the Norwegian Directorate of Fisheries for providing necessary data on farm location, biomass, and lice.

\section{LITERATURE CITED}

Aasetre J, Vik J (2013) Framing the environment - disputes and developments in the management of Norwegian Salmon Fjords. Ocean Coast Manag 71:203-212
Amundrud TL, Murray AG (2009) Modelling sea lice dispersion under varying environmental forcing in a Scottish sea loch. J Fish Dis 32:27-44

Asplin L, Boxaspen KK, Sandvik AD (2004) Modelled distribution of sea lice in a Norwegian fjord. ICES C.M. 2004/P:11. International Council for the Exploration of the Sea, Copenhagen

Asplin L, Boxaspen KK, Sandvik AD (2011) Modeling the distribution and abundance of planktonic larval stages of Lepeophtheirus salmonis in Norway. In: Jones S, Beamish R (eds) Salmon lice: an integrated approach to understanding parasite abundance and distribution. Wiley-Blackwell, Oxford, p 31-50

Barlaup BT (2013) Redningsaksjonen for Vossolaksen ('Rescue action for Vosso salmon'). DN-utredning 1-2013. Direktoratet for Naturforvaltning, Trondheim

Berg OK, Berg M (1987) Migrations of sea trout, Salmo trutta L., from the Vardnes river in northern Norway. J Fish Biol 31:113-121

> Birkeland K (1996) Consequences of premature return by sea trout (Salmo trutta) infested with the salmon lice (Lepeophtheirus salmonis Krøyer): migration, growth, and mortality. Can J Fish Aquat Sci 53:2808-2813

Bjørn PA, Finstad B (1997) The physiological effects of salmon lice infection on sea trout post smolts. Nord J Freshw Res 73:60-72

Bjørn PA, Finstad B (2002) Salmon lice, Lepeophtheirus salmonis (Krøyer), infestation in sympatric populations of Arctic char, Salvelinus alpinus (L.), and sea trout, Salmo trutta (L.), in areas near and distant from salmon farms. ICES J Mar Sci 59:131-139

Bjørn PA, Finstad B, Kristoffersen R (2001) Salmon lice infection of wild sea trout and Arctic char in marine and freshwaters: the effects of salmon farms. Aquacult Res 32: 947-962

Bjørn PA, Finstad B, Kristoffersen R, McKinley RS, Rikardsen AH (2007) Differences in risks and consequences of salmon louse, Lepeophtheirus salmonis (Krøyer), infestation on sympatric populations of Atlantic salmon, brown trout, and Arctic charr within northern fjords. ICES J Mar Sci 64:386-393

Bjørn PA, Sivertsgård R, Finstad B, Nilsen R, Serra-Llinares RM, Kristoffersen R (2011) Area protection may reduce salmon louse infection risk to wild salmonids. Aquacult Environ Interact 1:233-244

Bjørn PA, Nilsen R, Serra-Llinares RM, Asplin L and others (2012) Lakselusinfeksjonen på vill laksefisk langs Norskekysten i 2012 ('Sea lice infection of wild salmonids along the Norwegian coast in 2012'). Sluttrapport til Mattilsynet. Rapport fra havforskningen 31. Havforskningsinstituttet, Bergen

Boxaspen K, Næss T (2000) Development of eggs and planktonic stages of salmon lice (Lepeophtheirus salmonis) at low temperatures. Contrib Zool 69:51-55

> Bush AO, Lafferty KD, Lotz JM, Shostak AW (1997) Parasitology meets ecology on its own terms: Margolis et al. revisited. J Parasitol 83:575-583

> Butler JR (2002) Wild salmonids and sea louse infestations on the west coast of Scotland: sources of infection and implications for the management of marine salmon farms. Pest Manag Sci 58:595-608

Butler JRA, Watt J (2003) Assessing and managing the impacts of marine salmon farms on wild Atlantic salmon in western Scotland: identifying priority rivers for conservation. In: Mills D (ed) Salmon at the edge. Blackwell 
Science, Oxford, p 93-118

Costello MJ (2006) Ecology of sea lice parasitic on farmed and wild fish. Trends Parasitol 22(10):475-483

Costello MJ (2009) How sea lice from salmon farms may cause wild salmonid declines in Europe and North America and be a threat to fishes elsewhere. Proc R Soc Lond B Biol Sci 276(1672):3385-3394

> Davidsen JG, Plantalech Manella N, Økland F, Diserud $\mathrm{OH}$ and others (2008) Changes in swimming depths of Atlantic salmon Salmo salar post-smolts relative to light intensity. J Fish Biol 73:1065-1074

DKMD (Det kongelige miljødepartement) (2006) Om vern av villaksen og ferdigstilling av nasjonale laksevassdrag og laksefjorder ('Protection of wild Atlantic salmon and completion of National Salmon Fjords'). Stortingsproposisjor no. 32, Det kongelige miljødepartement, Oslo

Fast MD, Ross NW, Muise DM, Johnson SC (2006) Differential gene expression in Atlantic salmon infected with Lepeophtheirus salmonis. J Aquat Anim Health 18: 116-127

Finstad B, Bjørn PA (2011) Present status and implications of salmon lice on wild salmonids in Norwegian coastal zones. In: Jones S, Beamish R (eds) Salmon lice: an integrated approach to understanding parasite abundance and distribution. Wiley-Blackwell, Oxford, p 281-305

Finstad B, Bjørn PA, Grimnes A, Hvidsten NA (2000) Laboratory and field investigations of salmon lice [Lepeophtheirus salmonis (Krøyer)] infestation on Atlantic salmon (Salmo salar L.) post-smolts. Aquacult Res 31:795-803

Finstad B, Økland F, Thorstad EB, Bjørn PA, McKinley RS (2005) Migration of hatchery-reared Atlantic salmon and wild sea trout post-smolts in a Norwegian fjord system. J Fish Biol 66:86-96

Finstad B, Kroglund F, Strand R, Stefansson SO and others (2007) Salmon lice or suboptimal water quality-reasons for reduced postsmolt survival? Aquaculture 273:374-383

Finstad B, Bjørn PA, Todd CD, Whoriskey F, Gargan PG, Forde G, Revie C (2011) The effect of sea lice on Atlantic salmon and other salmonid species. In: Aas $\varnothing$, Einum $S$, Klemetsen A, Skurdal J (eds) Atlantic salmon ecology. Wiley-Blackwell, Oxford, p 253-276

Gargan PG, Tully O, Poole WR (2003) The relationship between sea lice infestation, sea lice production and sea trout survival in Ireland, 1992-2001. In: Mills D (ed) Salmon at the edge. Blackwell Science, Oxford, p 119-135

> Gargan PG, Forde G, Hazon N, Russell DJF, Todd CD (2012) Evidence for sea lice-induced marine mortality of Atlantic salmon (Salmo salar) in western Ireland from experimental releases of ranched smolts treated with emamectin benzoate. Can J Fish Aquat Sci 69:343-353

Gillibrand PA, Willis KJ (2007) Dispersal of sea louse larvae from salmon farms: modelling the influence of environmental conditions and larval behaviour. Aquat Biol 1: 63-75

> Grimnes A, Jakobsen PJ (1996) The physiological effects of salmon lice infection on post-smolt of Atlantic salmon. J Fish Biol 48:1179-1194

> Heuch PA, Mo TA (2001) A model of salmon louse production in Norway: effects of increasing salmon production and public management measures. Dis Aquat Org 45: 145-152

Heuch PA, Nordhagen JR, Schram TA (2000) Egg production in the salmon louse [Lepeophtheirus salmonis (Krøyer)] in relation to origin and water temperature. Aquacult Res 31:805-814
Heuch PA, Bjørn PA, Finstad B, Holst JC, Asplin L, Nilsen F (2005) A review of the Norwegian 'National Action Plan Against Salmon Lice on Salmonids': the effect on wild salmonids. Aquaculture 246:79-92

Holst JC, Jakobsen P, Nilsen F, Holm M, Asplm L, Aure J (2003) Mortality of seaward-migrating post-smolts of Atlantic salmon due to salmon lice infection in Norwegian salmon stocks. In: Mills D (ed) Salmon at the edge. Blackwell Science, Oxford, p 93-118

Ibrahim AA, MacKinnon BM, Burt MDB (2000) The influence of sub-lethal levels of zinc on smoltifying Atlantic salmon Salmo salar and on their subsequent susceptibility to infection by Lepeophtheirus salmonis. Contrib Zool 69:119-128

> Jackson D, Kane F, O'Donohoe P, Mc Dermott T, Kelly S, Drumm A, Newell J (2013) Sea lice levels on wild Atlantic salmon, Salmo salar L., returning to the coast of Ireland. J Fish Dis 36:293-298

> Jansen PA, Kristoffersen AB, Viljugrein H, Jimenez D, Aldrin M, Stien A (2012) Sea lice as a density dependent constraint to salmonid farming. Proc R Soc Lond B Biol Sci 279:2330-2338

Jensen KW (1968) Sea trout (Salmo trutta L.) of the River Istra, western Norway. Rep Inst Freshw Res Drottningholm 48:185-213

Johnsen IA (2011) Dispersion and abundance of salmon lice (Lepeophtheirus salmonis) in a Norwegian fjord system. MSc thesis, University of Bergen

> Johnson SC, Albright LJ (1991) Development, growth, and survival of Lepeophtheirus salmonis (Copepoda: Caligidae) under laboratory conditions. J Mar Biol Assoc UK 71:425-436

> Johnson SC, Fast MD (2004) Interactions between sea lice and their hosts. Symp Soc Exp Biol 55:131-159

Krkošek M, Hilborn R (2011) Sea lice (Lepeophtheirus salmonis) infestations and the productivity of pink salmon (Oncorhynchus gorbuscha) in the Broughton Archipelago, British Columbia, Canada. Can J Fish Aquat Sci 68:17-29

Krkošek M, Lewis MA, Volpe JP (2005) Transmission dynamics of parasitic sea lice from farm to wild salmon. Proc R Soc Lond B Biol Sci 272:689-696

Krkošek M, Lewis MA, Morton A, Frazer LN, Volpe JP (2006) Epizootics of wild fish induced by farm fish. Proc Natl Acad Sci USA 103:15506-15510

Krkošek M, Ford JS, Morton A, Lele S, Myers RA, Lewis MA (2007) Declining wild salmon populations in relation to parasites from farm salmon. Science 318:1772-1775

Krkošek M, Crawford WR, Patrick G, Gargan PG, Skilbrei OT, Finstad B, Todd CD (2013) Impact of parasites on salmon recruitment in the Northeast Atlantic Ocean. Proc R Soc Lond B Biol Sci 280:(1750):20122359

Lyse AA, Stefansson SO, Fernö A (1998) Behaviour and diet of sea trout post-smolts in a Norwegian fjord system. J Fish Biol 52:923-936

> Marty GD, Saksida SM, Quinn TJ II (2010) Relationship of farm salmon, sea lice, and wild salmon populations. Proc Natl Acad Sci USA 107:22599-22604

- Middlemas SJ, Raffell JA, Hay DW, Hatton-Ellis M, Armstrong JD (2010) Temporal and spatial patterns of sea lice levels on sea trout in western Scotland in relation to fish farm production cycles. Biol Lett 6:548-551

Middlemas SJ, Fryer RJ, Tulett D, Armstrong JD (2013) Relationship between sea lice levels on sea trout and fish farm activity in western Scotland. Fish Manag Ecol 20: $68-74$ 
Mo TA, Heuch PA (1998) Occurrence of Lepeophtheirus salmonis (Copepoda: Caligidae) on sea trout (Salmo trutta) in the inner Oslo Fjord, south-eastern Norway. ICES J Mar Sci 55:176-180

Morton A, Routledge R, Peet C, Ladwig A (2004) Sea lice (Lepeophtheirus salmonis) infection rates on juvenile pink (Oncorhynchus gorbuscha) and chum (Oncorhynchus keta) salmon in the nearshore marine environment of British Columbia, Canada. Can J Fish Aquat Sci 61: 147-157

Morton A, Routledge R, Krkošek M (2008) Sea louse infestation in wild juvenile salmon and Pacific herring associated with fish farms off the east-central coast of Vancouver Island, British Columbia. N Am J Fish Manag 28: 523-532

Nolan DT, Reilly P, Bonga SW (1999) Infection with low numbers of the sea louse Lepeophtheirus salmonis induces stress-related effects in postsmolt Atlantic salmon (Salmo salar). Can J Fish Aquat Sci 56:947-959

NOU (Norges Offentlige Utredninger) (1990) LENKA Landsomfattende egnethetsvurdering av den norske kystsonen og vassdragene for akvakultur ('LENKA Nationwide suitability assessment of the Norwegian coastal zone and rivers for aquaculture'). Fiskeridepartementet, Oslo (in Norwegian with English summary)

NOU (Norges offentlige utredninger) (1999) Til laks åt allekan ingen gjera? Om årsaker til nedgangen i de norske villlaksbestandene of forslag til strategier og tiltak for å bedre situasjonen ('Is it not possible to satisfy everyone? The reasons for the decline in the Norwegian wild salmon stocks and proposed strategies and measures to improve the situation'), Statens forvaltningstjeneste. Norges offentlige utredninger 9, Miljøverndepartementet, Oslo

Rikardsen AH (2004) Seasonal occurrence of sea lice Lepeophtheirus salmonis on sea trout in two north Norwegian fjords. J Fish Biol 65:711-722

Rikardsen AH, Amundsen PA, Bjørn PA, Johansen M (2000) Comparison of growth, diet and food consumption of searun and lake-dwelling Arctic charr. J Fish Biol 57: 1172-1188

Salama NKG, Collins CM, Fraser JG, Dunn J, Pert CC, Murray AG, Rabe B (2013) Development and assessment of a biophysical dispersal model for sea lice. J Fish Dis 36: 323-337

Schram TA (1993) Supplementary descriptions of the developmental stages of Lepeophtheirus salmonis (Krøyer, 1837) (Copepoda: Caligidae). In: Boxshall GA, Defaye D (eds) Pathogens of wild and farmed fish: sea lice. Ellis Horwood, New York, NY, p 30-47

$>$ Schram TA, Knutsen JA, Heuch PA, Mo TA (1998) Seasonal occurrence of Lepeophtheirus salmonis and Caligus elongatus (Copepoda: Caligidae) on sea trout (Salmo trutta), off southern Norway. ICES J Mar Sci 55:163-175

Sivertsgård R, Thorstad EB, Økland F, Finstad B and others (2007) Effects of salmon lice infection and salmon lice protection on fjord migrating Atlantic salmon and brown trout post-smolts. Hydrobiologia 582:35-42

Skilbrei OT, Finstad B, Urdal K, Bakke G, Kroglund F, Strand R (2013) Impact of early salmon louse, Lepeophtheirus salmonis, infestation and differences in survival and marine growth of sea-ranched Atlantic salmon, Salmo salar L., smolts 1997-2009. J Fish Dis 36:249-260

Sønvisen SA (2003) Integrated coastal zone management (ICZM): the allocation of space in Norwegian aquacul- ture - from local lottery to central planning? MSc thesis, Norwegian College of Fishery Science, University of Tromsø

> Stien A, Bjørn PA, Heuch PA, Elston DA (2005) Population dynamics of salmon lice Lepeophtheirus salmonis on Atlantic salmon and sea trout. Mar Ecol Prog Ser 290: 263-275

Stucchi DJ, Guo M, Foreman MGG, Czajko P, Galbraith M, Mackas DL, Gillibrand PA (2011) Modeling sea lice production and concentrations in the Broughton Archipelago, British Columbia. In: Jones S, Beamish R (eds) Salmon lice: an integrated approach to understanding parasite abundance and distribution. Wiley-Blackwell, Oxford, p 117-150

Taranger GL, Svåsand T, Kvamme BO, Kristiansen TS, Kroon Boxaspen K (eds) (2013) Risikovurdering norsk fiskeoppdrett 2012 ('Risk assessment of Norwegian aquaculture 2012'). Fisken og havet, særnummer 2-2013. Institute of Marine Research, Bergen

Taranger GL, Svåsand T, Bjørn PA, Jansen PA and others (2012) Forslag til førstegenerasjons målemetode for miljøeffekt (effektindikatorer) med hensyn til genetisk påvirkning fra oppdrettsfisk til villaks, og påvirkning av lakselus fra oppdrett på viltlevende laksebestander. ('Suggestions for first generation indicators for environmental impacts of salmon farming with respect to genetic influence and effect of sea lice on wild salmon populations'). Rapport fra Havforskningsinstituttet. Institute of Marine Research, Bergen

Thorstad E, Finstad B, Sivertsgrd R, Bjorn PA, McKinleyd R (2004) Migration speeds and orientation of Atlantic salmon and sea trout post-smolts in a Norwegian fjord system. Environ Biol Fishes 71:305-311

Thorstad EB, Økland F, Finstad B, Sivertsgård R, Plantalech N, Bjørn PA, McKinley RS (2007) Fjord migration and survival of wild and hatchery-reared Atlantic salmon and wild brown trout post-smolts. Hydrobiologia 582:99-107

Tingley GA, Ives MJ, Russell IC (1997) The occurrence of lice on sea trout (Salmo trutta L.) captured in the sea off the East Anglian coast of England. ICES J Mar Sci 54: $1120-1128$

Torrissen O, Jones S, Asche F, Guttormsen A and others (2013) Salmon lice-impact on wild salmonids and salmon aquaculture. J Fish Dis 36:171-194

> Tveiten H, Bjørn PA, Johnsen HK, Finstad B, McKinley RS (2010) Effects of the sea louse Lepeophtheirus salmonis on temporal changes in cortisol, sex steroids, growth and reproductive investment in Arctic charr Salvelinus alpinus. J Fish Biol 76:2318-2341

Vitenskapelig råd for lakseforvaltning (2011) Status for norske laksebestander i 2011 ('Status of Norwegian salmon stocks in 2011'). Rapport fra Vitenskapelig råd for lakseforvaltning no. 3. NINA, Trondheim

Vitenskapelig råd for lakseforvaltning (2012) Lakselus og effekter på vill laksefisk-fra individuell respons till bestandseffekter ('Salmon lice and effects on wild salmonids-from individual response to population effects'). Temarapport fra Vitenskapelig råd for lakseforvaltning no. 3. NINA, Trondheim

> Wagner GN, McKinley RS, Bjørn PA, Finstad B (2003) Physiological impact of sea lice on swimming performance of Atlantic salmon. J Fish Biol 62:1000-1009

Wagner GN, Fast MD, Johnson SC (2008) Physiology and immunology of Lepeophtheirus salmonis infections of salmonids. Trends Parasitol 24:176-183 